\title{
Microcallus growth from maize protoplasts
}

\author{
C. Imbrie-Milligan*, K.K. Kamo and T.K. Hodges \\ Department of Botany and Plant Pathology, Purdue University, West Lafayette, IN 47907, USA
}

\begin{abstract}
Maize (Zea mays L.) protoplasts obtained from Type I and Type II calli from several genotypes were shown to be capable of synthesizing cell walls and forming small clusters of cells. The medium used also supported cluster formation from protoplasts obtained from root tips. The effects of various additions to the medium (such as casein hydrolysate, coconut water, amino acids, sugars, phytohormones, nitrate, calcium, and dimethylsulfoxide as well as $\mathrm{pH}$ variations on cellcluster formation were determined. The method of culture (protoplasts plated in agarose or supported in alginate beads in liquid medium) as well as several components of the medium were found to be critical for microcallus formation. Protoplasts obtained from embryogenic Type I callus and cultured in the medium of C. Nitsch and J.P. Nitsch (1967, Planta 72, 355-370) modified by various additions (NN 67-mod medium) were affected most by various sugars, casein hydrolysate, coconut water, and a combination of the auxins naphthalene-1-acetic acid ( $2 \mathrm{mg} / \mathrm{l})$ and 2,4-dichlorophenoxyacetic acid $(0.1 \mathrm{mg} / \mathrm{l})$, and the cytokinin $\mathrm{N}^{6}$-benzylaminopurine $(0.5 \mathrm{mg} / 1)$. Cluster size in the agarose culture system was from 0.1 to $0.5 \mathrm{~mm}$ diameter and in the alginate culture system, up to $2.0 \mathrm{~mm}$ diameter.
\end{abstract}

Key words: Callus (Type I, II) - Microcallus - Protoplast culture $-\mathrm{Zea}$ (protoplasts).

\section{Introduction}

Protoplasts are well suited for genetic engineering experiments since they can be used for somatic hy-

\footnotetext{
* Present address: Department of Biological Chemistry, Uni-
} versity of Michigan, Ann Arbor, MI 48109, USA bridization and for direct DNA uptake providing the protoplasts can be induced to grow back into callus and eventually plants. While protoplasts from a number of species have been shown to regenerate callus and plants, it has been impossible to induce consecutive divisions in cultures of protoplasts isolated from many species of economic importance, such as cereals (see e.g. King et al. 1978). The limitations inherent in protoplast-regeneration techniques of agricultural plants represent a serious impediment to the advancement of in-vitro methods for crop improvement.

Success in protoplast culture depends on a large spectrum of variables including plant material from which the protoplasts are isolated (the choice of tissue as well as the developmental stage of that tissue), the genotype of the plant from which the protoplasts are isolated, and the components of the medium in which the protoplasts are cultured. The behavior of nonregenerating protoplasts may be attributed to a loss of genetic material or to a physiological block incurred by the enzymatic removal of the cell wall and by the culture conditions of the protoplasts. With the maize inbred line A 188 , it is relatively easy to induce and maintain callus cultures from which plants can be regenerated (Green 1982; Kamo et al. 1985; Vasil and Vasil 1986). This indicates the totipotency of at least some of the callus cells and supports the view that certain aspects of the protoplast isolation procedures or culture conditions, rather than a genetic defect, prevent the sustained divisions of protoplasts. A physiological block could be a consequence of a number of factors. The lack of a factor or precursor in the medium critical for wall formation or cell division could prevent the protoplasts from developing. The protoplasts might not grow because of the presence of inhibitors in the plating medium (Kohlenbach and Wernicke 1977) or in- 
hibitors produced by the cell such as phenolic substances (Carlberg et al. 1983), abscisic acid (Johansson et al. 1982), or the contents of dead cells. The removal of the wall has been shown to destabilize protoplasts leading to aging as measured by ethane formation, decrease in oxygen evolution and $\mathrm{CO}_{2}$ uptake, pigment degradation, and change in enzyme activities (Schnabl et al. 1983). Immobilization of plant protoplasts delays the appearance of aging (Schnabl and Youngman 1985; Schnabl et al. 1983; Linsefors and Brodelius 1985). The physiological block could be the result of other factors such as the disappearance of the cortical microtubular net as was shown to be the case with protoplasts from a Hibiscus cell line (Hahne and Hoffmann 1984). For maize protoplasts, we have evaluated the effect of the plant material and genotype from which the protoplasts were isolated, the culture conditions, and the medium components on protoplast viability and subsequent divisions.

\section{Material and methods}

Plant material. An embryogenic callus (Type I) derived from immature embryos of Zea mays L. was used as described by Kamo et al. (1985). The inbred line A188 was used for all experiments (except in Table 1). Seeds were obtained from either The Minnesota Crop Improvement Association, University of Minnesota, St. Paul, USA or from Dr. Charles Tsai, Purdue University. The callus was used for protoplast isolation after three weeks in culture on a MS basal salts medium (Murashige and Skoog 1962) with $2 \%$ sucrose, $100 \mathrm{mg} / \mathrm{l}$ myoinositol, $1.0 \mathrm{mg} / 1$ 2,4-dichlorophenoxyacetic acid (2,4-D), and modified White's vitamins (White 1963). The protoplast-isolation conditions and purification procedures were as described in ImbrieMilligan and Hodges (1986). In the initial experiments, other tissues as well as Type II callus (Green 1982; Hodges et al. 1985), were used for protoplast isolations. Root tips (terminal $10 \mathrm{~mm}$ of the root minus the root cap) and leaf sections $(5 \mathrm{~mm}$ region of leaf base) were obtained from seedlings grown for one week on half-strength MS salts with $1 \%$ sucrose.

Isolation and purification of protoplasts. Protoplasts were cultured in basal medium described by Nitsch and Nitsch (1967) but with various additions (this medium is referred to here as NN67-mod). The NN67-mod medium contained (in $\mathrm{mg} / 1$ ): $\mathrm{Ca}\left(\mathrm{NO}_{3}\right)_{2} \cdot 4 \mathrm{H}_{2} \mathrm{O}(500), \mathrm{KNO}_{3}(125)$,

$\mathrm{MgSO}_{4} \cdot 7 \mathrm{H}_{2} \mathrm{O}(325), \mathrm{MnSO}_{4} \cdot \mathrm{H}_{2} \mathrm{O}(25)$,

$\mathrm{H}_{3} \mathrm{BO}_{3}(10), \mathrm{ZnSO}_{4} \cdot 7 \mathrm{H}_{2} \mathrm{O}(10)$

$\mathrm{Na}_{2} \mathrm{MoO}_{4} \cdot 2 \mathrm{H}_{2} \mathrm{O}(25), \mathrm{CuSO}_{4} \cdot 5 \mathrm{H}_{2} \mathrm{O}(0.025)$,

$\mathrm{CoCl}_{2} \cdot 6 \mathrm{H}_{2} \mathrm{O}(0.025)$,

$\mathrm{Na}$ salt of ethylenediaminetetraacetic acid (EDTA) (7.45), $\mathrm{FeSO}_{4} \cdot 7 \mathrm{H}_{2} \mathrm{O}(5.557)$, glycine (2.0), nicotinic acid (5.0), pyridoxine $\cdot \mathrm{HCl}(0.5)$, thiamine $\cdot \mathrm{HCl}(0.5)$, biotin $(0.05)$, folic acid (0.05), 2,4-D (2.0), myoinositol (100.0), casein hydrolysate $(200.0)$, and (in $g / 1)$ : proline (2.3), sucrose (20.0), mannitol (109.2), arabinose $(0.125)$, cellobiose $(0.125)$, fructose $(0.125)$, mannose $(0.125)$, ribose $(0.125)$, xylose $(0.125)$, and coconut water $(20.0 \mathrm{ml} / \mathrm{l})$. Chemicals were obtained from Sigma Chemical Co., St Louis, Mo., USA, except for coconut water which was obtained from Gibco Laboratories, Chagrin Falls, O., USA. The NN67-mod medium was used for all exper- iments except as altered by specific additions in different experiments - see figures and tables.

Culture methods: agarose. Protoplasts were embedded and cultured in a thin layer of $0.4 \%$ low-melting-point (LMP) agarose (Bethesda Research Laboratories, Gaithersburg, Md., USA) in NN67-mod plus $2 \mathrm{mg} / 12,4-\mathrm{D}$ on top of $5 \mathrm{ml}$ of already solidified medium (of same composition) in 6-cm diameter Petri dishes. The cultures were kept in the dark at $26^{\circ} \mathrm{C}$ for four weeks.

Microcallus formation was quantified by counting the number of clusters (clusters were defined as three or more cells) from six fields per plate for two plates per treatment. All the experiments were performed twice with at least two plates per treatment.

Culture methods: alginate. Protoplasts were resuspended in NN67-mod with $2 \mathrm{mg} / 12,4-\mathrm{D}$ minus the calcium. The protoplast mixture was gently mixed with sodium alginate $(1 \% \mathrm{w} / \mathrm{v}$ in NN67-mod without the calcium) and then added dropwise to a flask containing NN67-mod with $80 \mathrm{mM} \mathrm{CaCl}_{2}$, forming beads of alginate with protoplasts entrapped in the beads. The flask was placed onto a shaker at $70 \mathrm{rpm}$ and kept in the dark at $26^{\circ} \mathrm{C}$. Media were replaced at various time intervals. Cells were released from the alginate matrix by complexing the calcium ions with $20 \mathrm{mM}$ sodium-citrate buffer, $\mathrm{pH} 6.0$ and shaking at $40 \mathrm{rpm}$ for $2-3 \mathrm{~h}$. The cell clusters were pelleted in a conical, graduated tube and the packed cell volume (PCV) was recorded. The clusters were then plated on Nucleopore (Nuclepore Corp., Pleasanton, Cal., USA) or Whatman filters over N6 (Chu et al. 1975) basal salts medium with $2 \mathrm{mg} / 1$ 2,4-D.

Cluster formation. For quantitative estimation of viability with both culturing techniques, fluorescein diacetate staining was used (Widholm 1972). Protoplasts were counted using a hemacytometer and plated at a density of $1 \cdot 10^{6}$ to $2 \cdot 10^{6}$ protoplasts $\mathrm{ml}^{-1}$. To find a culture medium which supported continued cell division in the protoplast cultures, several medium components such as phytohormones, nitrogen sources, carbon sources, $\mathrm{pH}$, dimethylsulfoxide (DMSO) and calcium concentrations were varied. A range of plant materials and genotypes was used for protoplast isolation and culture. Culture conditions such as temperature and transfer schedule were also varied.

\section{Results and discussion}

Source of protoplasts. It is possible to isolate protoplasts from virtually any plant tissue (see review by Evans and Bravo 1983). However, the tissue and genotype of the donor plant from which protoplasts are derived is important in determining whether cultured protoplasts will divide and form callus (Morgan and Cocking 1982). Callus, root tips, shoot tips and immature embryos from a number of maize genotypes were used for protoplast isolation. Type I callus derived from immature embryos of the inbred line A188 gave the highest yield of viable protoplasts and these protoplasts had the highest efficiency of cluster formation (Table 1). The basis for the different responses of genotypes and explants with regard to protoplast release and viability as well as subsequent growth is unknown. 
Table 1. Number of viable protoplasts isolated and the subsequent cell-cluster formation from different explants and genotypes of maize using the agarose culture system. Protoplasts were isolated from several different corn genotypes and several different tissues of these genotypes. In each case $1.5 \mathrm{~g} \mathrm{FW}$ of tissue was used per $10 \mathrm{ml}$ of enzyme incubation medium (except for immature embryos where $0.2-0.5 \mathrm{~g} \mathrm{FW}$ was used). Protoplasts were cultured in agarose with NN67-mod for four weeks. Type II callus is a friable, rapidly growing callus selected from Type I callus. $+++=$ good cluster formation (25-50 clusters/ field); $++=$ average cluster formation $(10-25$ clusters/field); $+=$ some cluster formation $(1-10$ clusters/field $) ;-=$ no cluster formation

\begin{tabular}{|c|c|c|c|}
\hline Explant & Genotype & $\begin{array}{l}\text { Viable } \\
\text { proto- } \\
\text { plasts/g FW }\end{array}$ & $\begin{array}{l}\text { Cluster } \\
\text { formation }\end{array}$ \\
\hline \multicolumn{4}{|l|}{ Callus } \\
\hline \multirow[t]{9}{*}{ Type I } & A188 & $23.54 \cdot 10^{6}$ & +++ \\
\hline & B73 & 0 & - \\
\hline & $\mathrm{B} 73 \cdot \mathrm{A} 188$ & $0.002 \cdot 10^{6}$ & - \\
\hline & W64A & $0.02 \cdot 10^{6}$ & - \\
\hline & W64A $\cdot A 188$ & $0.57 \cdot 10^{6}$ & $+t$ \\
\hline & A188.W64A & $0.64 \cdot 10^{6}$ & ++ \\
\hline & Mo17 & $0.02 \cdot 10^{6}$ & + \\
\hline & Mo17·A188 & $0.22 \cdot 10^{5}$ & - \\
\hline & A188 Mo17 & $0.17 \cdot 10^{6}$ & + \\
\hline \multirow[t]{2}{*}{ Type II } & A188 & $0.26 \cdot 10^{6}$ & $++t$ \\
\hline & B $73 \cdot A 188$ & $0.09 \cdot 10^{6}$ & ++ \\
\hline \multirow[t]{3}{*}{ Roots } & A188 & $0.57 \cdot 10^{6}$ & $t+$ \\
\hline & B73 & $1.63 \cdot 10^{6}$ & ++ \\
\hline & Mo17 & $0.54 \cdot 10^{6}$ & + \\
\hline \multirow{2}{*}{$\begin{array}{l}\text { Shoots } \\
\text { Immature } \\
\text { embryos }\end{array}$} & A188 & $0.34 \cdot 10^{6}$ & - \\
\hline & A188 & $2.49 \cdot 10^{6}$ & - \\
\hline
\end{tabular}

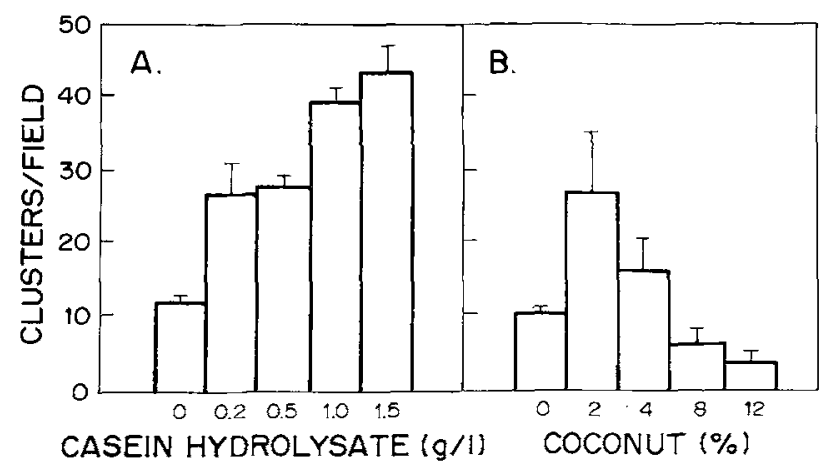

Fig. 1 A, B. Effect of casein hydrolysate (A) and coconut water (B) on cluster formation from protoplasts cultured in the agarose system with NN67-mod for four weeks

Effects of casein hydrolysate, coconut water and nitrogenous compounds. Casein hydrolysate and coconut water were both essential for a high efficiency of microcallus formation (Fig. 1). High levels of casein hydrolysate $(1.0-1.5 \mathrm{~g} / \mathrm{l})$ increased the efficiency of cluster formation from protopiasts, indicating the importance of nitrogen and/or free amino acids. While nitrate was essential, ammonium inhibited the formation of clusters from proto-

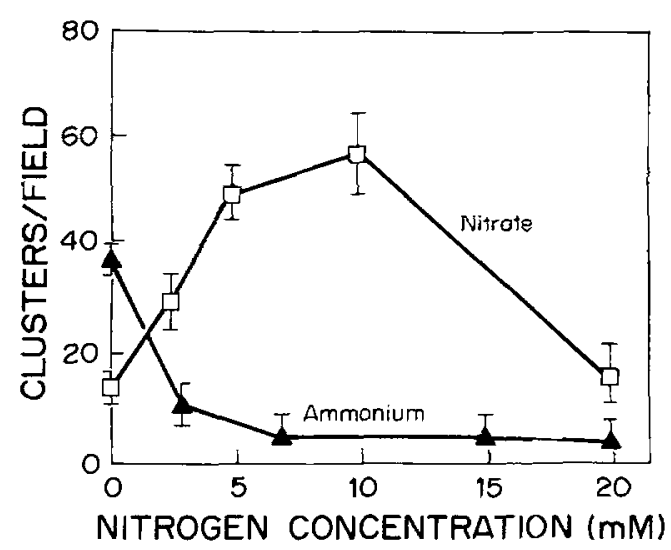

Fig. 2. Effect of nitrogen source on cluster formation from maize protoplasts cultured in the agarose system with NN67mod for four weeks. Nitrate was added as $\mathrm{KNO}_{3}$. Ammonium was added in the presence of $5 \mathrm{mM}$ nitrate as $\left(\mathrm{NH}_{4}\right)_{2} \mathrm{SO}_{4}$

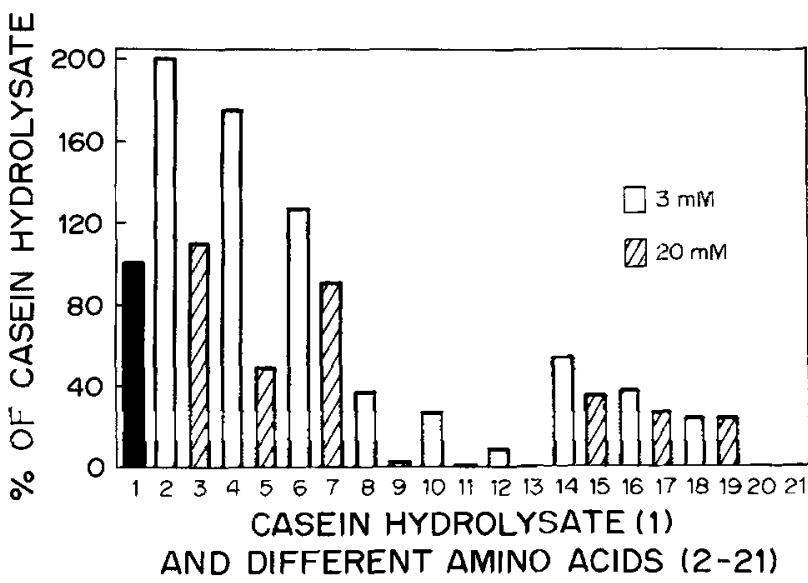

Fig. 3. Effect of free amino acids or amines at $3 \mathrm{mM}$ (open bars) and $20 \mathrm{mM}$ (notched bars) on the formation of clusters from maize protoplasts plated at $2 \cdot 10^{6}$ protoplasts $/ \mathrm{ml}$ with $0.2 \mathrm{~g} / 1$ of casein hydrolysate in the agarose system with NN67mod and cultured for four weeks. These figures are the percentage of clusters formed relative to the number of clusters formed with just casein hydrolysate $(=$ bar 1$)$ which averaged 32 clusters per field in this experiment. Amino acids or amines are as follows: $2,3=$ alanine; $4,5=$ proline; $6,7=$ glutamine; $8,9=$ glycine; $10,11=$ serine; $12,13=$ arginine; $14,15=$ lysine $; 16,17=$ isoleucine; $18,19=$ valine; $20,21=$ leucine

plasts (Fig. 2) as was found previously with Vicia (Kao and Michayluk 1975). Stuart and Street (1971) indicated that amino acids are part of the "conditioning factors" found beneficial for the growth of cultures of sycamore and maple cells. Bui-Dang-Ha and Mackenzie (1973) reported that the success of asparagus protoplast cultures depended, in large measure, on the presence of high levels $(1.0 \mathrm{~g} / 1)$ of glutamine in the growth medium. Of the ten amino acids tested here, only alanine, proline, and glutamine increased the production of clusters above the level produced with just casein hydrolysate (Fig. 3). Most of the amino acids 


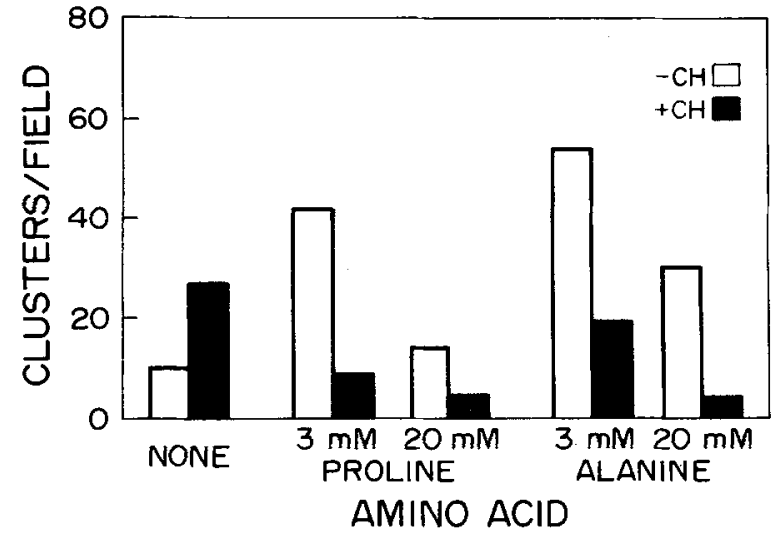

Fig. 4. Effect of alanine and proline on cluster formation from maize protoplasts cultured for four weeks in the presence or absence of $0.2 \mathrm{~g} / 1$ casein hydrolysate, using the agarose system with NN67-mod

Table 2. The effect of potential cell-wall precursor sugars on cell-cluster formation from maize protoplasts in the agarose culture system. The concentration of the various sugar additives was $0.125 \mathrm{~g} / 1$. The basal salts medium was NN67-mod and the culture period was four weeks

\begin{tabular}{ll}
\hline Sugar & $\begin{array}{l}\text { No. clusters/field } \\
(\text { mean } \pm \text { SD) }\end{array}$ \\
\hline - Sugars & $2.2 \pm 1.5$ \\
+ Arabinose & $2.7 \pm 1.0$ \\
+Cellobiose & $3.7 \pm 2.8$ \\
+ Fructose & $3.3 \pm 2.0$ \\
+ Galactose & $2.2 \pm 1.9$ \\
+ Glucuronic acid & $6.5 \pm 3.6$ \\
+ Mannose & $1.6 \pm 1.2$ \\
+ Ribose & $4.0 \pm 1.4$ \\
+ Xylose & $2.7 \pm 1.4$ \\
+ All sugars & $27.1 \pm 9.2$ \\
\hline
\end{tabular}

inhibited cluster formation. Additionally, proline and alanine at $3 \mathrm{mM}$ were effective in promoting cluster formation in the absence of casein hydrolysate (Fig. 4). High levels of glutamine (200 or $1000 \mathrm{mg} / 1)$ did not significantly increase the number of clusters formed (data not shown).

Cell-wall precursors. The addition of small amounts $(0.125 \mathrm{~g} / 1)$ of eight potential cell-wall precursors added together increased the number of clusters formed by 12 -fold (Table 2). Addition of the sugars individually indicated that no one sugar was responsible for the increase in cluster formation.

$p H$, calcium, myoinositiol, nucleoside triphosphates, and temperature. The importance of $\mathrm{pH}$ of the culture medium has been examined in a number of systems. While a $\mathrm{pH}$ range of 5.5-5.7 appears to be useful for a wide range of species (Landgren
Table 3. Effect of different temperature regimes on the development of cell clusters from maize protoplasts in the agarose culture system. Protoplasts were cultured in agarose with NN67mod. They were kept at the first temperature for the time indicated and were then transferred to a different temperature for the remainder of the 28 -d treatment. All cultures were kept in the dark

\begin{tabular}{lcc}
\hline $\begin{array}{l}\text { Temperature } \\
\left({ }^{\circ} \mathrm{C}\right)\end{array}$ & $\begin{array}{l}\text { Time at } \\
\text { initial temperature } \\
\text { (d) }\end{array}$ & $\begin{array}{l}\text { No. clusters/field } \\
\text { (mean } \pm \mathrm{SD})\end{array}$ \\
\hline 15 to 26 & 7 & $13.5 \pm 2.3$ \\
& 14 & $5.1 \pm 1.3$ \\
21 to 26 & 28 & $5.3 \pm 1.3$ \\
& 14 & $24.8 \pm 3.1$ \\
26 & 28 & $26.4 \pm 4.5$ \\
26 to 21 & 28 & $27.4 \pm 3.1$ \\
& 4 & $35.8 \pm 3.8$ \\
& 7 & $12.8 \pm 2.1$ \\
& 14 & $14.8 \pm 4.9$ \\
& 28 & $21.3 \pm 3.9$ \\
\hline
\end{tabular}

1976; Chin and Scott 1979; Hess and Leipoldt 1979), for maize $\mathrm{pH} 6.0$ was best for both protoplast isolation and culture (data not shown). The addition of Mes buffer (2-[N-morpholino] ethanesulfonic acid) at $0.5 \%(\mathrm{w} / \mathrm{v})$ to the plating medium, which had been shown to promote protoplast growth in some systems (Koop et al. 1983), had no effect on maize protoplast cultures. High calcium $(12 \mathrm{mM})$ has been shown to stimulate protoplast survival and cell division in pea (Von Arnold and Eriksson 1977). The effect of calcium concentration on cluster formation in maize was tested by varying the $\mathrm{CaCl}_{2}$ concentration over a range of $0,2,5,20$ and $80 \mathrm{mM}$. Calcium was required for cluster formation, with $5 \mathrm{mM} \mathrm{Ca}^{2+}$ giving the highest number of clusters (data not shown).

While high concentrations of myoinositol are important in tomato protoplast culture (Shahin 1983), myoinositol had no marked effect on cluster formation when included over a range of 0 to $1 \%$. Nucleoside triphosphates (adenosine-, cytidine-, guanosine- and thymidine-5'-triphosphate at $10^{-4} \mathrm{M}$ ) and adenine (also at $10^{-4} \mathrm{M}$ ) did not increase the number of clusters formed from plated protoplasts. Sucrose was the preferred carbon source over glucose. Incubation of the protoplasts at $26^{\circ} \mathrm{C}$ resulted in a greater number of clusters than other temperature regimes tested (Table 3 ).

Culture conditions. Maize protoplasts cultured in liquid medium did not form cell walls or undergo any cell divisions (data not shown). Protoplasts supported in an agarose (Tables 1-3, 7: Figs. 1-5) 
Table 4. Maize protoplast growth as determined by packed cell volume (PCV) after various periods in the alginate culture system. Protoplasts were entrapped in alginate beads and kept in liquid medium (NN67-mod) for various amounts of time (from 4 to $20 \mathrm{~d}$ ) before they were released from the beads with sodium citrate. Liquid medium was replaced at $4-d$ intervals

\begin{tabular}{ll}
$\begin{array}{l}\text { Time in alginate } \\
\text { (d) }\end{array}$ & $\begin{array}{l}\text { Growth as PCV } \\
(\mathrm{ml} \pm \mathrm{SD})\end{array}$ \\
\hline 4 & 0 \\
8 & $0.03 \pm 0.02$ \\
12 & $0.19 \pm 0.04$ \\
16 & $0.17 \pm 0.03$ \\
20 & $0.18 \pm 0.06$ \\
\hline
\end{tabular}

or an alginate matrix (Tables 4-7) formed cell walls and divided several times. In the agarose system (Imbrie-Milligan and Hodges 1986), and under the best conditions developed to date (with various growth regulators, see next section) cluster size ranged from 0.1 to $0.5 \mathrm{~mm}$. Maize protoplasts immobilized in alginate drops suspended in liquid medium and shaken at $70 \mathrm{rpm}$ grew to cluster sizes of $1.5-2.0 \mathrm{~mm}$ in diameter. In both culture systems the new cell clusters remained viable for up to $6-$ 8 weeks as assessed by fluorescein-diacetate staining. For microcallus formation, the protoplasts had to remain in the alginate beads for at least $12 \mathrm{~d}$, after which maintaining the protoplasts in alginate did not significantly increase growth of the cells (Table 4). The number of viable protoplasts rapidly declined if the alginate drops were shaken faster $(120 \mathrm{rpm})$ or not at all $(0 \mathrm{rpm})$ (data not shown). Since the alginate matrix is permeable to water (Scheurich et al. 1980), the medium could be completely and easily replaced. Replacing the medium often (at 2- or 4-d intervals) increased growth as measured by packed cell volume after $28 \mathrm{~d}$ in culture (Table 5). One cannot compare the agarose culture system and the alginate culture system with regard to numbers of clusters formed; however, as already mentioned the cluster size achieved was about five- to tenfold greater in the alginate system.

Growth regulators. Different growth regulators have been tested extensively in various protoplast culture media. 2,4-Dichlorophenoxyacetic acid (2,4-D) is the most commonly used auxin for protoplast culture (Evans and Bravo 1983). However, Uchimiya and Murashige (1976) observed a higher plating efficiency when naphthalene-1-acetic acid (NAA) was used instead of 2,4-D or indole-3-acetic acid (IAA). Of the auxins tested in this study, both 2,4-D and NAA (at $2 \mathrm{mg} / 1$ ) resulted in good cluster
Table 5. Maize protoplast growth as measured by packed cell volume $(\mathrm{PCV})$ as a function of the frequency of replacing the nutrient medium in the alginate culture system. The NN67-mod medium was replaced at different frequencies (every $2,4,7$, $14 \mathrm{~d}$ or not at all) over a $28 \mathrm{-d}$ culture period. At the end of $28 \mathrm{~d}$, the cell clusters were released from the alginate beads and PCV was measured

\begin{tabular}{ll}
\hline $\begin{array}{l}\text { Transfer schedule } \\
\text { (d) }\end{array}$ & $\begin{array}{l}\text { Growth as PCV } \\
(\mathrm{ml} \pm \mathrm{SD})\end{array}$ \\
\hline 2 & $0.16 \pm 0.05$ \\
4 & $0.20 \pm 0.06$ \\
7 & $0.08 \pm 0.03$ \\
14 & $0.05 \pm 0.03$ \\
28 & 0 \\
\hline
\end{tabular}

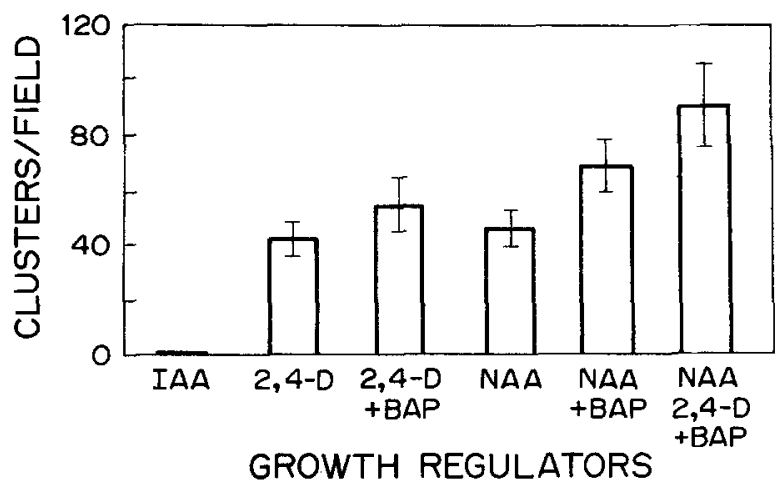

Fig. 5. Effect of various auxins by themselves or with the cytokinin BAP (at $0.5 \mathrm{mg} / 1$ ) on cluster formation from maize protoplasts cultured in the agarose system with NN67-mod for four weeks. Each bar represents the optimal concentration of that auxin from a range of concentrations tested $(0-40 \mathrm{mg} / \mathrm{l}$ for IAA, $0-4 \mathrm{mg} / 1$ for $2,4-\mathrm{D}$ and $0-10 \mathrm{mg} / 1 \mathrm{NAA}$ ). The optimal concentration of both 2,4-D and NAA separately was $2.0 \mathrm{mg} / \mathrm{l}$. The bar farthest to the right represents a combination of NAA at $2.0 \mathrm{mg} / 1,2,4-\mathrm{D}$ at $0.1 \mathrm{mg} / 1$, and BAP at $0.5 \mathrm{mg} / 1$

formation (Fig. 5). The addition of $0.5 \mathrm{mg} / 1$ of the cytokinin, $\mathrm{N}^{6}$-benzylamino-purine (BAP) to either auxin improved cluster formation (Fig. 5). The combination of NAA, 2,4-D, and BAP gave the highest number of clusters per field which was about two-fold higher than reported previously (Imbrie-Milligan and Hodges 1986). Zeatin (6-[4-hydroxy-3-methylbut-2-enylamino] purine), kinetin ( $\mathrm{N}^{6}$-furfuryl-aminopurine), and isopentenyl adenine (IPA) were also tested over a range of concentrations $(0-10 \mathrm{mg} / \mathrm{l})$. Kinetin (at $0.01 \mathrm{mg} /$ l) and IPA (at $5.0 \mathrm{mg} / \mathrm{l}$ ) both increased the number of clusters formed but only by a small amount (seven or eight additional clusters per field). Benzylaminopurine (at $0.5 \mathrm{mg} / \mathrm{l}$ ) had the greatest effect with 15-18 additional clusters per field (an increase of about $50 \%$ ). Gibberellic acid $\left(\mathrm{GA}_{3}\right)$, added to the medium at $0,2,5,10$, or $100 \mathrm{mg} / 1$, had no significant effect on the number of clusters 
Table 6. Maize protoplast growth measured as packed cell volume (PCV) when osmoticum (mannitol concentration) in the alginate culture system was lowered at different frequencies. The mannitol concentration of the NN67-mod medium ranged from $0.6 \mathrm{M}$ mannitol to $0 \mathrm{M}$ mannitol and was introduced to the alginate beads at various times after protoplast isolation. Liquid medium was replaced every $4 \mathrm{~d}$ over a $24-\mathrm{d}$ culture period

\begin{tabular}{llllll}
\hline \multicolumn{3}{l}{ Mannitol concn. (M) during days } & & $\begin{array}{l}\text { Growth } \\
\text { as PCV } \\
\text { (ml } \pm \text { SD) }\end{array}$ \\
\hline $0-4$ & $4-8$ & $8-12$ & $12-16$ & $16-20$ & $0.17 \pm 0.02$ \\
0.6 & 0.6 & 0.6 & 0.6 & 0.6 & $0.28 \pm 0.05$ \\
0.6 & 0.4 & 0.2 & 0 & 0 & $0.18 \pm 0.06$ \\
0.6 & 0.6 & 0.4 & 0.2 & 0 & \\
\hline
\end{tabular}

formed, while abscisic acid, added over a range of $0-2 \mu \mathrm{M}$, inhibited cluster formation with $20 \%$ fewer clusters formed with $0.01 \mu \mathrm{M} \mathrm{ABA}$, and about $50 \%$ fewer clusters formed with $0.20 \mu \mathrm{M}$. The addition of NAA and BAP also increased the number of clusters formed when protoplasts were cultured in alginate beads (threefold, from a PCV of $0.06 \mathrm{ml}$ with NN67-mod to a PCV (packed cell volume) of $0.18 \mathrm{ml}$ in NN67-mod with $1 \mathrm{mg} / 1$ NAA, $0.1 \mathrm{mg} / 12,4-\mathrm{D}$ and $0.5 \mathrm{mg} / 1$ of BAP).

Osmoticum. The effect of transfer to low osmoticum was examined by transferring protoplasts to NN67-mod without mannitol after 1, 2, 4, 7, 21, or $28 \mathrm{~d}$. Protoplasts were osmotically sensitive until one week after plating when they could be transferred to medium containing no special osmoticum (i.e. other than the basal salts and sugars). There were no differences in the number of clusters formed with any of the other transfer schedules. The number of clusters formed was similar when the osmoticum was decreased gradually during the first week or decreased abruptly after one week in culture (data not shown). Also, the transfer of plated protoplasts at one, two, or three weeks to high salt NN67 (NN67 with Murashige and Skoog macro- and micronutrients) with no mannitol or $0.6 \mathrm{M}$ mannitol did not increase the number of cell clusters formed. Decreasing the osmoticum gradually increased cluster formation from protoplasts immobilized in alginate (Table 6).

Dimethyl sulfoxide (DMSO) increased the number of clusters formed when protoplasts were plated in solid medium, and doubled the number of clusters formed even when the protoplasts were plated at a lower density $\left(2 \cdot 10^{5}\right.$ protoplasts $\left./ \mathrm{ml}\right)$ than normally required for efficient cluster formation (Table 7). However, these clusters did not continue to divide and approx. $90 \%$ were dead after one
Table 7. Effect of DMSO on protoplast growth measured as either packed cell volume (alginate culture system) or number of cell clusters formed (agarose culture system). The DMSO was added to the NN67-mod medium in the alginate bead system or into the protoplast/agarose gel of the agarose system at various concentrations; PCV or the number of clusters formed was measured after $28 \mathrm{~d}$ in culture

\begin{tabular}{llll}
\hline $\begin{array}{l}\text { DMSO } \\
(\%, \mathrm{v} / \mathrm{v})\end{array}$ & \multicolumn{2}{l}{ Protoplast growth } \\
\cline { 2 - 4 } & $\begin{array}{l}\text { PCV } \\
(\mathrm{ml} \pm \mathrm{SD})\end{array}$ & $\begin{array}{l}\text { No. cell clusters/field } \\
\text { (mean } \pm \text { SD) formed, using } \\
\text { a protoplast density of } \ldots\end{array}$ \\
\cline { 3 - 4 } & & $2 \cdot 10^{5}$ & $2 \cdot 10^{6}$ \\
\hline 0 & $0.20 \pm 0.04$ & $8.2 \pm 5.7$ & $34.3 \pm 6.5$ \\
1 & $0.32 \pm 0.09$ & $-\mathbf{a}$ & $-\mathbf{a}^{\mathrm{a}}$ \\
2 & $0.36 \pm 0.04$ & $20.7 \pm 5.2$ & $50.8 \pm 15.5$ \\
4 & $0.01 \pm 0.03$ & $6.3 \pm 6.3$ & $11.1 \pm 3.0$ \\
\hline
\end{tabular}

Not determined

month in culture, indicating that a prolonged exposure to DMSO had a toxic effect. When DMSO was included in the culture medium with protoplasts in the alginate beads (Table 7), the volume of cell clusters formed could be increased by about twofold ( $2 \%$ DMSO). For this effect to be seen, the protoplasts had to be exposed to DMSO for at least $4 \mathrm{~d}$ while longer exposures were detrimental (data not shown). Glycerol, which like DMSO affects microtubule assembly, did not promote the formation of clusters from alginate-immobilized clusters (data not shown).

\section{Conclusions}

The first step in protoplast regeneration is always the preparation of healthy protoplasts, which is usually dependent on the quality of the plants or cells used for the isolation as well as the isolation procedures. The protoplast preparation described previously (Imbrie-Milligan and Hodges 1986) and used here results in the isolation of large numbers of viable maize protoplasts and the culturing techniques employed (an agarose and an alginate system) support protoplast growth for several weeks. We have tested a variety of medium components and found some of them to be essential for the division and vigorous growth of the protoplasts.

It is difficult to compare directly the results from the two plating techniques described here since in the agarose cultures it is easy to determine the numbers of cell clusters formed, but it is somewhat difficult to obtain an estimate of the packed cell volume. The opposite is true for the alginate cultures which appear to result in fewer clusters 
(per initial protoplast isolated), but the clusters grow to a greater size. Protoplasts grown in the alginate system are also easier to manipulate in that media components can be readily changed, and the cell clusters can be released readily from the supporting matrix by complexing the $\mathrm{Ca}^{2+}$

The authors thank Nancy Petretic, Sandra Schroll and Ka-Lai Chang for excellent technical assistance and Agrigenetics Corp., Boulder, Co., USA for financial support. This is Journal Paper No. 10775 of the Purdue University Agricultural Experiment Station.

\section{References}

Bui-Dang-Ha, D., Mackenzie, I.A. (1973) The division of protoplasts from Asparagus officinalis L. and their growth and differentiation. Protoplasma 78, 215-221

Carlberg, I., Glimelius, K., Eriksson T. (1983) Improved culture ability of potato protoplasts by use of activated charcoal. Plant Cell Rep. 2, 223-225

Chin, J.C., Scott, K.J. (1979) A large scale isolation procedure for cereal mesophyll protoplasts. Ann. Bot. 43, 23-32

Chu, C.C., Wang, C.C., Sun, C.S., Hsu, C., Yin, K.C., Chu, C.Y. (1975) Establishment of an efficient medium for anther culture of rice through comparative experiments on the nitrogen sources. Sci. Sinica 18, 659-668

Evans, D.A., Bravo, J.E. (1983) Protoplast isolation and culture. In: Handbook of plant cell culture, pp. 124-176, Evans, D.A., Sharp, W.R. Ammirato, P.V., Yamada, Y., eds. Academic Press, New York

Green, C.E. (1982) Somatic embryogenesis and plant regeneration from the friable callus of Zea mays. In: Plant tissue culture 1982 (Proc. V. Int. Congr. Plant Tissue and Cell Culture), pp. 107-108, Fujuwara, A., ed. Japanese Association for Plant Tissue Culture, Tokyo, Japan

Hahne, G., Hoffmann, F. (1984) Dimethyl sulfoxide can initiate cell divisions of arrested callus protoplasts by promoting cortical microtubule assembly. Proc. Natl. Acad. Sci. USA 81, 5449-5453

Hess, D., Leipoldt, G. (1979) Regeneration of shoots and roots from isolated mesophyll protoplasts of Nemesia strumosa. Biochem. Physiol. Pfl. 174, 411-417

Hodges, T.K., Kamo, K.K., Becwar, M.R., Schroll, S. (1985) Regeneration of maize. In: Biotechnology in plant science: revelence to agriculture in the eighties, pp. 15-33, Zaitlin, M., Day, P., Hollaender, A., eds. Academic Press, New York

Imbrie-Milligan, C.W., Hodges, T.K. (1986) Microcallus formation from maize protoplasts prepared from embryogenic callus. Planta 168, 395-401

Johansson, L., Andersson, B., Eriksson, T. (1982) Improvement of anther culture technique: Activated charcoal bound in agar medium in combination with liquid medium and elevated $\mathrm{CO}_{2}$ concentration. Physiol. Plant. 54, 24-30

Kamo, K.K., Becwar, M.R., Hodges, T.K. (1985) Regeneration of Zea mays L. from embryogenic callus. Bot. Gaz. 146, 327-334

Kao, K.N., Michayluk, M.R. (1975) Nutrient requirements for growth of Vicia hajastana cells and protoplasts at a very low population density in liquid media. Planta 126, 105-110

King, P.J., Potrykus, I., Thomas, E. (1978) In vitro genetics of cereal: Problems and perspectives. Physiol. Vég. 16, 381-399

Kohlenbach, H.W., Wernicke, W. (1977) Investigations on the inhibitory effect of agar and the function of active carbon in anther culture. Z. Pflanzenphysiol. 86, 463-472

Koop, H.-U., Weber, G., Schweiger, H.-G. (1983) Individual culture of selected single cells and protoplasts of higher plants in microdroplets of defined media. Z. Pflanzenphysiol. 112, 21-34

Landgren, C.R. (1976) The influence of culture conditions on mitotic activity in protoplasts derived from Pisum root cortical explants. Protoplasma 87, 49-69

Linsefors, L., Brodelius, P. (1985) Immobilization of plant protoplasts: Viability studies. Plant Cell Rep. 4, 23-27

Morgan, A., Cocking, E.C. (1982) Plant regeneration from protoplasts of Lycopersicum esculentum Mill. Z. Pflanzenphysiol. 106, 97-104

Murashige, T., Skoog, F. (1962) A revised medium for rapid growth and bioassay with tobacco tissue culture. Physiol. Plant. 15, 473-497

Nitsch, C., Nitsch, J.P. (1967) The induction of flowering in vitro in stem segments of Plumbago indica L. II. The production of reproductive buds. Planta 72, 355-370

Rao, P.S. (1982) Protoplast culture. In: Experimental embryology of vascular plants, pp. 231-262, Johri, B.M., ed. Springer, Berlin

Scheurich, P., Schnabl, H., Zimmermann, U., Klein, J. (1980) Immobilisation and mechanical support of individual protoplasts. Biochim. Biophys. Acta 598, 645-651

Schnabl. H., Youngman, R.J. (1985) Immobilisation of plant cell protoplasts inhibits enzymic lipid peroxidation. Plant Science 40, 65-69

Schnabl, H., Youngman, R.J., Zimmermann, U. (1983) Maintenance of plant cell membrane integrity and function by the immobilisation of protoplasts in alginate matrices. Planta 158, 392-397

Shahin, E.A. (1983) Totipotency of tomato protoplasts. Theor. Appl. Gen. 69, 235-240

Stuart, R., Street, H.E. (1971) Studies on the growth in culture of plant cells. X. Further studies on the conditioning of culture media by suspensions of Acer pseudoplatanus $\mathrm{L}$. cells. J. Exitl. Bot 22, 96-106

Uchimiya, H., Murashige, T. (1976) Influence of the nutrient medium on the recovery of dividing cells from tobacco protoplasts. Plant Physiol. 57, 424-429

Vasil, V., Vasil, I.K. (1986) Plant regeneration from friable embryogenic callus and cell suspension cultures of Zea mays L. J. Plant Physiol. 124, 399-408

Von Arnold, S., Eriksson, T. (1977) A revised medium for growth of pea mesophyll protoplasts. Physiol. Plant. 39, $257-260$

White, P.R. (1963) The cultivation of animal and plant cells. Ronald Press, New York

Widholm, J.M. (1972) The use of fluorescein diacetate and phenosafranin for determining viability of cultured plant cells. Stain Technol. 47, 189-193

Received 10 July 1986; accepted 21 January 1987 